\title{
Path Dependence or Convergence? The Evolution of Corporate Ownership Around the World*
}

\author{
ANDY J.Y. YEH, STEVEN LIM, AND ED VOS \\ Reserve Bank of New Zealand; Economics, University of Waikato; \\ Finance, University of Waikato
}

We offer a model that sheds light on the debate over whether corporate ownership concentration converges to the Berle-Means image. Our model takes into account the importance of both legal rules and firm-specific arrangements. Our analytical result is that share ownership concentration either persists or falls depending on the relative importance of these protective arrangements. In particular, our model predicts: (a) diffuse corporate ownership in nations that impose legal limits on blockholders' clout to expropriate minority shareholder rights, and (b) concentrated corporate ownership in nations that rely on asset specificity as a form of investor protection.

Our empirical work suggests partial convergence toward Berle-Means diffuse share ownership. It is thereby reasonable to infer the existence of path dependent forces on ownership concentration. But this result does not preclude the possibility of functional convergence or convergence to the diffuse form of share ownership via cross-listings on the major U.S. stock exchanges that impose stringent disclosure and listing requirements. In essence, these results suggest a case for the co-existence of the preexisting path-dependency and functional-convergence stories.

JEL Keywords: ownership dispersion, institutions, corporate governance, quality of governance, path dependence, and functional convergence, Berle-Means diffuse ownership

\footnotetext{
* Corresponding author andrew.yeh@rbnz.govt.nz. Andy J.Y. Yeh, Reserve Bank of New Zealand; Steven Lim, Economics Department, University of Waikato; and Ed Vos, Finance Department, University of Waikato. We would like to acknowledge the financial assistance of the Reserve Bank of New Zealand, Treasury New Zealand, and the University of Waikato. Further, we are indebted to Glenn Boyle, Kiwi A.D. Camara, Jack Coffee, Gerrit De Geest (the editor), David Goddard, Johanne Grosvold, Abeyratna Gunasekarage, Rebecca Hawthorne, Ed Kane, Sam Y.P. Kao, Mervyn Lewis, Andrew M. Lin, Daphne J. Lin, Alex Ng, Cath Sleeman, Liesle Theron, Clive Thorp, Alireza Tourani-Rad, James Twaddle, Bruce White and the anonymous referees for their thoughts and comments. The usual disclaimer applies to this paper, and all remaining errors are our own responsibility.
} 
We offer a model that sheds light on the debate over whether corporate ownership concentration converges to the Berle-Means image that is diffuse in stock ownership concentration. Our model takes into account the importance of both legal rules and firm-specific arrangements. Our analytical result is that share ownership concentration either persists or falls depending on the relative importance of these protective arrangements. Our model predicts: (a) diffuse share ownership in nations that impose legal limits on blockholders' clout to expropriate minority shareholder rights, and (b) concentrated share ownership in nations that rely on asset specificity as a form of investor protection.

An empirical examination of the data shows that the level of corporate ownership concentration has persisted over the period from 1994 to 2003. But this result does not preclude the possibility of 'functional convergence' convergence to the diffuse form of share ownership through cross-listings on U.S. stock exchanges that impose both stringent disclosure and listing requirements to dampen share ownership concentration. These results suggest a case for the co-existence of the preexisting path-dependency and functionalconvergence stories.

Some skeptics question the relevance of this debate. This attack rests on a couple of dimensions. The first dimension concerns the fact that states unlike producers in a competitive market - may not operate as price takers. States can often use their de facto authority to set the legal terrain on which competition takes place (Greenwood, 2005). If most states aim to receive more corporate tax revenue ${ }^{1}$, these states can choose to 'go nuclear', for instance, by subsidizing local companies, to retain control of the existing onshore

\footnotetext{
${ }^{1}$ Several accounts frame the debate over the race to the top or the bottom. For instance, Cary (1974) outlines the race to the bottom in corporate law, and Winter (1977) describes the race to the top in corporate law. Recent discussions seem to have revived the 'race' debate. Bebchuk (1992) suggests that state competition may lead to the adoption of undesirable corporate legal rules. This legal change is likely to lead to a race to the bottom in the presence of managerial opportunism and externalities. But several factors could inadvertently result in the failure of state competition. Romano (1993) discusses the event studies in support of the view that the U.S. corporate law regime is not a product of state competition. Bebchuk, Cohen, and Ferrell (2002) suggest that the empirical results do not support the case for state competition. Further, Bebchuk and Hamdani (2002) argue a case for some form of federal intervention to empower shareholders to initiate and approve re-incorporations. It is important to note that we use the phrases, 'the race to the top' and 'the race to the bottom', as the race for all market participants to improve or downgrade the existing body of corporate law rules and securities regulations. These participants encompass companies, executives, directors, shareholders, and regulators. The recent discussions on the race debate suggest that state competition may not be the key determinant of rules governing corporate matters. Our treatment entails a more holistic view; we focus on whether cross-listings facilitate the race to the top from a global perspective. In contrast, the discussions as cited above focus on the effect of state competition (in the U.S.) on the quality of governance.
}

Review of Law \& Economics, ( 2007 by bepress 
arrangements that may not be optimal. Hence, states may have the power to create legal hurdles to deter such convergence. In this light, convergence towards any one-size-fits-all solution may not be plausible because bureaucrats who politicize corporate law prevent self-regulation to emerge. Political debate poses social costs and in turn may render the convergence process inefficient. By this line of reasoning the convergence debate that we explore in this study is neither a race to the top nor a race to the bottom. In this rather pessimistic view, the convergence story is not inevitable and so lacks policy implications.

We accept the view that states can exert influence over the legal conditions for corporate power-sharing and ownership schemes. But this view overlooks one of the key roles of government: to build a sustainable, facilitative legal system that allows market competition to take place. Today's global economy is a doubletiered market. The first tier consists of companies with international reach. In contrast, the second tier comprises companies that concentrate their regional exposures. Even in the case where states operate to attract corporate taxes, it is possible to design a double-tiered legal framework as a response. Companies that concentrate on-shore exposures adhere to the rules and norms in a given country. For companies that operate across countries, compliance with a set of strict governance standards signals better quality. As a result, an improvement in the quality of governance promotes better outcomes. Over the long run, states and investors benefit from the success of these companies because they generate larger corporate tax revenue and tend to have a propensity to emulate the most effective and efficient ownership structures. In essence, state control should not totally preclude the case for (partial) convergence.

A second potential source of skepticism relates to the patterns of share ownership concentration around the world. Recent studies show that commonlaw regimes appear to outperform civil-law regimes in shaping an environment in which securities markets can prosper (La Porta et al., 1997, 1998, 1999, 2002; Demirguc-Kunt and Maksimovic, 1998:2134). Common-law countries have an average ratio of publicly traded shares to Gross National Product of 0.60 , but the same ratio is only 0.21 for French civil-law countries and 0.45 for German civillaw countries. The U.K. has 36 listed firms per million citizens and the U.S. has 30, but France, Germany and Italy have only 8, 4, and 5 respectively. Hence, law does matter. If the U.S., the U.K., Japan and some other countries with BerleMeans listed companies represent most of the value of the global stock market, why is it relevant to examine the patterns of ownership concentration in the other countries? In order to overcome this objection and to better understand the underlying trends, we look at cross-country share ownership patterns, and more generally, the evolution of corporate power-sharing schemes. This focus could allow us to explain why differences in ownership concentration and 
governance may or may not persist. More importantly this paper explains why share ownership concentration could affect the tilt of corporate power and thus the quality of governance as well as why certain governance practices help enhance outcomes.

The remainder of the paper has the following structure. Section 1 briefly frames the debate over whether the form of share ownership becomes diffuse over time. Section 2 presents a model that nests legal and firm-specific protections in the function of ownership concentration. This model synthesizes the path-dependence and convergence stories and thus serves as a basis for the subsequent empirical tests. Section 3 describes the data and discusses the empirical results. Section 4 concludes this paper.

\section{THE CONVERGENCE DEBATE}

\subsection{The NeOClassical CONVERgENCE Hypothesis}

In the neoclassical view, the Berle-Means form of the modern corporation has survived to date as this form of corporate ownership and governance best balances the costs of managerial control, risk-sharing, and capital needs. In a Darwinian evolution, the corporation is expected to mitigate agency problems with a board of directors, by use of debt, and with incentive-based pay schemes. Further, the joint threat of proxy contests, takeovers, and social norms can discipline corporate managers. In turn the modern corporation adapts to these competitive forces via fractional share ownership.

\subsubsection{The Rise of Fractional Corporate Ownership}

The market-oriented model creates a positive externality to investors and companies. Companies can be viewed as a 'nexus of contracts' (Jensen and Meckling, 1976; Jensen, 1986). Investors who spread their shareholdings across a number of firms reap risk-sharing benefits. Because investors provide capital to companies and grant monitoring power to directors, insofar as there are sound legal institutions that effectively protect minority shareholder rights, investors' key role is to offer liquidity to companies. By holding small shares, investors put funds into more firms and in turn benefit from diversification (Coffee, 1991:1284-1290, 1999, 2002; Maug, 1998). Hence, investors can choose to forego their direct control over management in order to retain the option to liquiddate diffuse shares in due course (Coffee, 2001:2-4).

Review of Law \& Economics, ( 92007 by bepress 
Path Dependence or Convergence? / 521

\subsubsection{Globalization and Systemic Adaptability}

The increasing globalization of capital markets is widely viewed as another competitive force that drives convergence towards the Berle-Means image of the modern company. Multinational firms can opt into better regulatory regimes. The U.S. and U.K. securities markets are examples of such regimes that help enhance fiduciary protection of minority shareholder rights (Cunningham, 1999:1143-1146; Coffee, 1999, 2002). Deep and liquid stock markets that emphasize investor interests facilitate quick responses in times of stress. These strong market forces then serve as an external monitor. Examples of such an external monitor include (a) market analysts whose buy and/or sell recommendations can have a first-order effect on share prices, and (b) cross-border mergers and acquisitions that can involve an influx of new shareholders (Gordon, 1999:219-220).

\subsubsection{International Emulation}

Anglo-American corporate systems take the lead in shaping liquid markets and diffuse share ownership. This approach to corporate governance has been confrontational, relying on competition and division of responsibility to drive performance (Coffee, 1991:1280-1281, 1284-1290; Kissane, 1997:626-633). As a result, self-regulatory forces can arise from a desire to emulate a set of best practices in corporate governance. Many international organizations have been closely involved in the development of general principles of corporate governance. These efforts contribute to the prevalence of the theme that adherence to the shareholder-market model lead to better corporate outcomes (Hansmann and Kraakman, 2004). Evidence in support of the above assertion is that many Anglo-American companies have performed better as compared to both the principal East Asian and continental European companies, most of which deviate from the share-holder-market model (La Porta et al, 1999:480-491; Claessens et al., 2000:82-84, 94-99; Ayyagari, 2005).

\subsection{The PATH DEPENDENCE STORY}

Unlike proponents of the convergence story, others suggest a number of barriers to convergence toward the Berle-Means firm that is diffuse in stock ownership. Below we briefly discuss reasons why concentrated share ownership could persist over time. Our main goal is to explore the roots of the persistence of share ownership concentration. The potential reasons include politics, rent-protection behaviors, complementarities, sunk costs, and social norms of trust. 


\subsubsection{The Political Theory of Corporate Finance}

Some scholars contend that politics confines the terrain on which the large enterprise may evolve (Roe, 1991:11-13, 2000). This confinement subsequently shapes the efficient form of ownership to which the modern enterprise adapts. Also this confinement gives rise to specific power-sharing arrangements. For instance, U.S. populism leads to the common belief that no institution should have significant financial power (Roe, 1991:31-32; Lipset and Schneider, 1987:5-6; Acemoglu et al., 2001:1369-1370). The U.S. general public's mistrust of financial power could be viewed as an unequivocal case for laws that limit financial institutions' ownership of listed shares (Black, 1990; Coffee, 1991, 1999; Roe, 1991). In contrast, Germany and Japan lack the U.S.-style populism and operate a bank-oriented model. Most German and Japanese listed corporations tend to centralize decisions and rely on banks or other financial intermediaries for funding investment plans (Roe, 1993:1933-1936, 1994). Such examples show that politics sets the limits of financial institutions' reach in share ownership. In turn, these limits impart the main conditions for the separation of ownership and control in the corporate context.

\subsubsection{The Rent-Protection Theory of Corporate Ownership and Control}

Some scholars suggest that leaving corporate control up for grabs may attract attempts to acquire the company by rivals who seek to capture private benefits of control ${ }^{2}$ (Bebchuk, 1999; Benos and Weisbach, 2004). Concentrated equity blocks are likely to prevail in countries where private benefits of control are large. Such countries, for instance, as Italy and Brazil, appear to lack legal institutions that deter rent protection. In contrast, concentrated share ownership is likely to wane in countries that have robust legal rules in place to curtail private benefits of control.

If private benefits of control are large, corporate insiders usually face incentives not to subject the company to stringent disclosure and other listing rules. Doidge (2002, 2004), Doidge et al. (2005), and Benos and Weisbach (2004:234-238) find that private benefits of control tend to be larger in companies not crosslisting their shares abroad. East Asian companies that use pyramid structures, dual-class shares, and overseas crossholdings to enhance shareholders' grip of corporate control are another example of rent protection. Bebchuk et al. (1999) and La Porta et al. (1999) provide a detailed account of these arrangements.

\footnotetext{
2 Private benefits of control are often referred to as 'benefits that accrue to managers or [blockholders] that have control of the corporation but not to minority shareholders'. Examples are business connections, large office suites, , managers' retreat, and other perquisites.
}

Review of Law \& Economics, ( 2007 by bepress 
Path Dependence or Convergence? / 523

\subsubsection{A Nexus of 'Firm-Specific Investments,' Not a Nexus of 'Contracts'}

Some scholars reject the view that a company is a nexus of contracts. These scholars argue that a company could instead be viewed as a 'nexus of firmspecific investments' (Blair and Stout, 1999:275). Each team member devotes specialized, irrevocable efforts to the corporation. Employees carry out day-today operational tasks. Senior executives organize and oversee staff performance. Creditors and stock owners inject funds to support the firm's investment projects. The board of directors acts as a mediating hierarchy that integrates these efforts (Rajan and Zingales, 1998). A team member's efforts are 'specific' to the firm. In addition, each team member's investment has little or no value outside the joint enterprise. Also, no one can leave the enterprise and realize the value of the investment in full.

The status quo generally serves as one of multiple optima. If high switching costs are required to shift to an alternative optimum, continuance is often efficient (Bebchuk and Roe, 1999:139-142). A change in share ownership dispersion could result in inconsistencies between the new structure and the other elements of team production. Often times, the existing ownership and governance patterns are only second-best options. A good example can be Russian investors' preference for direct government control of large enterprises. In this case official intervention serves as an alter-native form of investor protection. If a shift to first-best structures (say, less government control) requires large switching costs and in turn leads to third-best outcomes, it may be best to maintain the status quo. Hence, complementary corporate structures are expected to persist over time.

\subsubsection{Social Norms of Fairness and Trust}

An extant literature suggests that social norms - such as fairness and trust - help shape the trajectory on which corporate structures evolve (Blair and Stout, 2001:1807-1810; Licht, 2001; Coffee, 2001). In the corporate context, the rules of the game often depend on what is perceived to be fair. Stakeholders see a mix of corporate power as unfair if this mix departs substantially from the terms of a reference transaction, which is a transaction setting the benchmark for some corporate interactions (Jolls et al., 1998:1493-1497). Due to cultural differences, the reference transaction may vary from country to country. For instance, American culture generally resists hierarchy and centralized authority more than French culture (Bebchuk and Roe, 1999:168-169). In Germany, codetermination reflects the need for a fair go for all employees (Roe, 1993:1942-1943). In East Asian 'dragon' economies, many large enterprises bribe government officials to seek protection (Claessens et al., 2000:83). Most Italian firms view family involvement as an 
indispensable value driver. If these cultural differences persist, corporate structures are most likely to remain close to their initial conditions.

\subsection{A CAUTIONARY Note}

We have framed the convergence debate. Proponents of both pathdependence and convergence stories seem to hold rather firm views on the evolution of corporate ownership dispersion. In an intuitive sense, the main forces that render corporate structures persistent may deter convergence towards the Berle-Means corporation. In particular, the path-dependence story suggests that the level of ownership concentration at any point in time depends on the initial condition. This static relation, however, may not constitute the full picture. In contrast, the convergence theory better describes the more dynamic part of the picture: cross-listings on U.S. stock exchanges allow nonU.S. firms to bond themselves to higher standards of corporate governance and in turn facilitate convergence toward diffuse share ownership. It is thereby reasonable to integrate the competing stories to paint a more complete picture.

In Section 2, we present a model that captures both the static and dynamic components of share ownership concentration. Our analysis helps detect the conditions for Berle-Means convergence. In particular, the model demonstrates that the degree of share ownership concentration could be decomposed into a) the initial condition, and b) the relative importance of legal and firm-specific protective mechanisms. This analysis motivates our empirical tests in Section 3.

\section{A UNIFIED THEORY}

\subsection{SOME BACKGROUND}

We derive a model to characterize the relationship between legal protection of investor rights and firm-specific provisions that help insulate minority shareholders, namely, inside share ownership concentration and asset endowment. Insiders can often commit to lower rates of value diversion by holding a large fraction of equity in the company (Himmelberg et al., 2002). In this case, share ownership entails an inexorable tradeoff between bonding incentives and risk-sharing benefits for insiders. How these insiders balance the tradeoff in turn determines the severity of agency costs. Legal rules that protect investor rights to corporate securities could well tilt this trade-off in favor of more diffuse share ownership. This conjecture arises from the fact that strong legal protection of investor rights enhances the value of equity in the large enterprise (La Porta et al., 1999, 2002). As a consequence, investor-friendly legal remedies could at least partly affect the equilibrium level of share ownership dispersion.

Review of Law \& Economics, ( 2007 by bepress 
Asset endowment also plays a role in setting the equilibrium level of share ownership dispersion. ${ }^{3}$ Highly specific assets, such as research labs, plant, property and equipment, and factories, require large sums of finance and are thus hard to steal. This idea relates to Blair and Stout's (1999) team production story. Each stakeholder's contribution to the corporate team complements the use of assets that are 'specific' to the company. Therefore stakeholders that leave the enterprise lose the additional value arising from the positive interplay between their human capital and asset use. In that light, highly specific assets provide a built-in degree of investor protection. On the contrary, assets such as technical know-how and on-the-job experience are easier to expropriate if insiders can readily leave to start their own ventures at a low cost (Himmelberg et al., 2002). Therefore, a lack of asset specificity may render investors more vulnerable to value diversion by insiders (Bebchuk and Jolls, 1999). In essence, asset specificity is at least as important as rules of law in approximating the degree of full investor protection.

Our model relates to a number of studies that shed light on the link between corporate structures and firm-specific asset endowments. In particular, highly specific assets lead to opportunities for private benefits of control. Corporate insiders' attempts to confiscate these private benefits lock in large blocks of stock. These attempts propagate information asymmetries arising from the fact that managers know more about the value of company assets than shareholders. As a result, such information asymmetries lead the company to choose share ownership and governance schemes that provide a suboptimal degree of investor protection (Bebchuk, 2002). Recent studies suggest that there are marked differences in share ownership and governance structures around the world (La Porta et al., 1998, 1999). While many economists suggest that the forces of globalization put ineluctable pressures on corporate structures to converge towards the most efficient genre (Easterbrook and Fischel, 1991:212213), others argue that rent-protection behaviors could result in the persistence of corporate structures (Bebchuk and Roe, 1999).

The subsequent derivation of our model builds on the discussions above. The prevailing level of inside share ownership concentration at any point in time can be expressed as a function of a) the initial level of share ownership concentration, b) 'asset protection' of investor rights, and c) 'legal protection' that inhibits shareholder value diversion. Given the relative weights assigned to

\footnotetext{
${ }^{3}$ Specific assets are referred to as assets for which it is hard to find substitutes. A good example can be 100 percent humanization mouse technology used in various biotech experiments. This particular kind of mouse technology differs from the 80-90 percent humanization alternatives in its robustness in many drug experiments.
} 
both asset and legal protections, our model predicts whether corporate ownership structures converge over time.

\subsection{MODEL SETUP AND DERIVATION}

Our proposed model builds upon a schematic Cobb-Douglas process that converts inputs factors into one single output variable. The Cobb-Douglas process is a standard concept that helps build the microeconomic foundation for our model of corporate ownership concentration. The Cobb-Douglas process also helps simplify the derivation of the model. We refer the input factors to the quality of both legal and asset protections of shareholder rights. In addition, we define the output variable as the full degree of investor protection. The underlying intuition is to convert legal and asset protections into a common unit of output that captures the full benefits of investor protection arising from the legal and asset arrangements. Table 1 provides the variable definitions below:

\section{Table 1: Variable definitions and mathematical notations}

\begin{tabular}{|c|c|}
\hline Notation & Definition \\
\hline$F_{0}(t)$ & $\begin{array}{l}\text { the full degree of investor protection arising from both legal and } \\
\text { firm-specific arrangements that protect investor rights at time } t\end{array}$ \\
\hline$f_{0}(t)$ & $\begin{array}{l}\text { the degree of asset protection of investor rights arising from } \\
\text { different levels of asset specificity at time } t\end{array}$ \\
\hline$x_{0}(t)$ & $\begin{array}{l}\text { the degree of investor protection arising from legal remedies that } \\
\text { govern corporate activities at time } t\end{array}$ \\
\hline$\alpha$ & $\begin{array}{l}\text { The factor share that reflects the relative importance of asset } \\
\text { protection of investor rights }\left(f_{0}(t)\right)\end{array}$ \\
\hline$\beta$ & $\begin{array}{l}\text { the factor share that reflects the relative importance of legal } \\
\text { protection of investor rights }\left(\mathrm{x}_{0}(\mathrm{t})\right)\end{array}$ \\
\hline$\varphi_{0}$ & the initial level of inside share ownership concentration \\
\hline$\varphi(t)$ & the current level of inside share ownership concentration at time $t$ \\
\hline
\end{tabular}

Review of Law \& Economics, ( 2007 by bepress 
Our proposed Cobb-Douglas process can be expressed as the following:

(1) $\mathrm{F}_{0}\left(\mathrm{f}_{0}(\mathrm{t}), \mathrm{x}_{0}(\mathrm{t})\right)=\mathrm{f}_{0}(\mathrm{t})^{\alpha} \mathrm{x}_{0}(\mathrm{t})^{\beta}$

Taking the natural log of each side of Eq.(1) yields a linear equation:

(2) $F(f(t), x(t))=\alpha f(t)+\beta x(t)$

where $\mathrm{F}=\ln \mathrm{F}_{0}, \mathrm{f}=\ln \mathrm{f}_{0}$, and $\mathrm{x}=\ln \mathrm{x}_{0}$ are the $\log$-transformed counterparts of the full, asset, and legal protections respectively. In Eq.(2) the factor shares, $\alpha$ and $\beta$, reflect the relative importance of the asset and legal conditions under which the economy operates. For instance, the U.S., Britain, and other Anglo-Saxon countries emphasize legal protection of shareholder rights. So these countries could be viewed as economies where $\alpha$ is smaller than $\beta$. In other words, these countries attach a larger weight to legal protection than to asset protection. In contrast, investors in countries such as Germany, Japan, and the so-called 'social democracies' in Continental Europe, rely upon asset protection of investor rights. Such countries could be viewed as economies where $\alpha$ is larger than $\beta$. Also, we assume that insiders benefit from positive stock ownership of the company $(0<\varphi<1)$. We scale this term by $F / f$, or $(\alpha f+\beta x) / f$, to measure the full degree of investor protection. Hence, the expression, $[\varphi \cdot(\alpha f+\beta x) / f]$, captures the full benefits of asset and legal protective arrangements arising from 100 percent inside share ownership. We scale this expression to capture the benefits of legal and asset protections arising from any partial stock ownership: $[\varphi \cdot(\alpha \mathrm{f}+\beta \mathrm{x}) / \mathrm{f}] \cdot \mathrm{d} \varphi$ where $d \varphi$ denotes a marginal change in share ownership.

Because diffuse ownership spreads the benefits of legal and asset protections to more owners, an economy's dispersion of share ownership creates a network externality to corporations. Investor protection hence goes hand in hand with share ownership concentration at the margin. We note that this assumption does not imply La Porta et al.'s evidence of a negative relationship between ownership concentration and legal protection of investor rights. Rather, this assumption suggests that a marginal change in full protection, $\mathrm{dF}$, can be expressed as a function of a marginal change in the full benefits of both legal and asset protections arising from 'partial' inside stock ownership as discussed above. In this case, $\mathrm{dF}$ and $\mathrm{d} \varphi$ move in opposite directions due to the spread effect of share ownership dispersion.

We assume that changes in the degree of full investor protection arising from either legal or asset protections are proportional to changes in the full benefits of legal and asset protections arising from partial inside share ownership of a given corporation. 


$$
\mathrm{dF}(\mathrm{f}(\mathrm{t}), \mathrm{f}(\mathrm{t}))=(-) \frac{1}{\mathrm{k}} \phi(\mathrm{x}(\mathrm{t}))\left(\frac{\alpha \mathrm{f}(\mathrm{t})+\beta \mathrm{x}(\mathrm{t})}{\mathrm{f}(\mathrm{t})}\right) \mathrm{d} \phi(\mathrm{x}(\mathrm{t}))
$$

where $\mathrm{k}>0$ is a proportionality scalar, and the negative sign on the right-hand side of Eq.(3) keeps intact the assumption that diffuse share ownership permits the full benefits of investor protection to spread to more owners.

We assume that the level of inside share ownership concentration depends on the degree of legal protection at any point in time. The reader might note that this characterization does not capture the protective effect of asset specificity. In other words, why is $\varphi(x(t))$ a function of $x(t)$ only but not a function of both $f(t)$ and $x(t)$ ? Our response to this question is twofold. First, the empirics support our characterization. We could view the level of inside share ownership concentration as a response to the degree of legal protection. As will be shown below, the solution to Eq.(3) sheds light on the nature of association between $\varphi(x(t))$ and $x(t)$. Second, we view the value of property rights as the value of legal rules that enforce these property rights, not the value of the underlying assets. Specific assets only have a good value if there are laws that protect the use of these assets. Examples of such laws include land laws and patent laws. Strong and robust legal institutions that protect rights to shares create incentives for investors to invest in publicly listed companies. This line of reasoning suggests that legal protection acts as the precondition for holding diffuse shares.

Rearranging Eq.(3) with the substitution of $\mathrm{dF} / \mathrm{d} \varphi=(\mathrm{dF} / \mathrm{dx})(\mathrm{dx} / \mathrm{d} \varphi)=\beta \mathrm{dx} / \mathrm{d} \varphi$ yields Eq.(4):

$$
\phi(x(t)) d \phi(x(t))=(-) k\left(\frac{\beta f(t)}{\alpha f(t)+\beta x(t)}\right) d x(t)
$$

Next, we integrate both sides of Eq. (4) to solve for $\varphi(x(t))$ :

$$
\phi(\mathrm{x}(\mathrm{t}))=\sqrt{\mathrm{c}-2 \mathrm{kf}(\mathrm{t}) \ln (\alpha \mathrm{f}(\mathrm{t})+\beta \mathrm{x}(\mathrm{t}))}
$$

where $\mathrm{c}$ is an arbitrary constant. As $\varphi(\mathrm{x}(\mathrm{t}))$ is strictly positive by definition, Eq.(5) should hold for plausible values of $k$, $\alpha$, and $\beta$. Let the initial condition be $\varphi(x(0))=\varphi(0)=\varphi_{0}$. We then obtain $\mathrm{c}=\varphi_{0}{ }^{2}+2 \mathrm{kf}(\mathrm{t}) \ln (\alpha \mathrm{f}(\mathrm{t}))$. Substituting this result into Eq.(5) yields the following:

$$
\left.\phi(\mathrm{x}(\mathrm{t}))\right|_{\phi(\mathrm{x}(0))=\phi(0)=\phi_{0}}=\sqrt{\phi_{0}^{2}+2 \mathrm{kf}(\mathrm{t}) \ln \left(\frac{\alpha \mathrm{f}(\mathrm{t})}{\alpha \mathrm{f}(\mathrm{t})+\beta \mathrm{x}(\mathrm{t})}\right)}
$$

Review of Law \& Economics, (C) 2007 by bepress 
Path Dependence or Convergence? / 529

We define the 'convergence determinant', $\theta(\mathrm{f}(\mathrm{t}), \mathrm{x}(\mathrm{t}))$, as the following:

$$
\theta(\mathrm{f}(\mathrm{t}), \mathrm{x}(\mathrm{t}))=2 \mathrm{kf}(\mathrm{t}) \ln \left(\frac{\alpha \mathrm{f}(\mathrm{t})}{\alpha \mathrm{f}(\mathrm{t})+\beta \mathrm{x}(\mathrm{t})}\right)
$$

Then we can simplify Eq.(6) to Eq.(8) below:

$$
\left.\phi(\mathrm{x}(\mathrm{t}))\right|_{\phi(\mathrm{x}(0))=\phi(0)=\phi_{0}}=\sqrt{\phi_{0}^{2}+\theta(\mathrm{f}(\mathrm{t}), \mathrm{x}(\mathrm{t}))}
$$

The convergence determinant, $\theta(\mathrm{f}(\mathrm{t}), \mathrm{x}(\mathrm{t}))$, sets the preconditions for stock ownership to converge to the Berle-Means form. If $\theta$ turns out to be substantially close to nil, $\varphi(\mathrm{x}(\mathrm{t}))$ remains close to $\varphi_{0}$ or stays path dependent over time. If $\theta$ is consistently negative over time, $\varphi(x(t))$ converges to nil because $\varphi(\mathrm{x}(\mathrm{t}))$ is bounded below by zero by definition. Also Eq.(6) shows that the level of inside stock ownership for a given degree of total investor protection at time $\mathrm{t}, \varphi(\mathrm{x}(\mathrm{t}))$, is either equal to or less than the initial level of inside share ownership concentration, $\varphi_{0}$, since the term inside the natural log cannot be greater than unity.

\subsection{DisCUSSIONS}

Eq. (6) suggests a couple of propositions. Firstly, the optimal level of ownership concentration is negatively related to the degree of legal protection of investor rights (ceteris paribus). Our model finds that this relationship is nonlinear. But this analytical result accords with the law-and-finance thesis: "ownership concentration serves as a substitute for poor investor protection" (La Porta et al., 1999:473-474, 497). Further, we note that Eq.(6) does not imply the same sort of association between share ownership concentration, $\varphi(x(t))$, and asset protection, $\mathrm{f}(\mathrm{t})$. Our analytical solution implies that there is an ambiguous relationship between share ownership concentration and asset protection. Endowed assets could be viewed as a natural product of the geographic environment in the era of colonial settlement and/or extraction. It is therefore reasonable to suggest that most firm-specific protections are exogenous due to historical contingencies such as colonization (Acemoglu et al., 2001). In essence, the effect of asset protection on share ownership concentration is not clear-cut.

Secondly, Eq.(6) supports the case for the path-dependence of share ownership concentration: "a country's pattern of corporate ownership structures at any point in time depends partly on the patterns it had at earlier 
times" (Bebchuk and Roe, 1999:129). This prediction sheds light on the company's share ownership concentration that could persist due to a number of factors such as network externalities, institutional complementarities, sunk adaptive costs, and multiple optima for corporate ownership and governance structures. In addition to these forces, rent-seeking behaviors accentuate the persistence of corporate structures (Bebchuk, 1999:14-17). The parties who intervene in corporate decisions under an existing structure might have both the incentive and power to hinder changes that would otherwise be socially efficient. Thus, the persistence of ownership and governance structures could be a natural outcome due to interest groups' attempts to retain their private benefits of corporate control.

We now discuss how a change in the relative weights, $\alpha$ and $\beta$, affects the property of ownership concentration. Consider a recent social democracy, for instance, Russia, in which cultural norms and political backlashes emphasize asset protection more than legal protection. In this case, $\alpha$ is larger than $\beta$, rendering $\theta$ close to zero. Given the initial condition $\varphi_{0}, \varphi(x(t))$ is likely to persist at $\varphi_{0}$ or the initial level of share ownership concentration. In other words concentrated ownership is likely to persist in social democracies where asset endowments are viewed as more important than legal remedies.

Now consider the Berle-Means corporation in which diffuse share ownership reflects sound legal protection of investor rights. This observation arises from a variety of reasons, such as relentless political backlashes, social norms of trust, and legal impediments that block financial institutions' control over corporations. In this case, $\alpha$ is smaller than $\beta$. Given any initial condition $\varphi_{0}$, $\varphi(\mathrm{x}(\mathrm{t}))$ is likely to converge to an insignificant size over time, ceteris paribus. We arrive at this result as a) $\varphi(\mathrm{x}(\mathrm{t}))$ is bounded below by zero, and $\mathrm{b}) \theta(\mathrm{f}(\mathrm{t}), \mathrm{x}(\mathrm{t}))$ is consistently negative and so drives $\varphi(\mathrm{x}(\mathrm{t}))$ to a relatively trivial term. Hence, it is likely for share ownership to become more and more diffuse in economies that emphasize legal protection of investor rights.

In Section 3, we explore whether convergence towards diffuse share ownership occurs in practice. Section 3 presents the data, describes the variables, and then discusses the results. Also, Section 3 provides robustness checks on the results. At the end of Section 3 we provide a brief summary of the key findings arising from this empirical work.

\section{EMPIRICAL EVIDENCE}

We test for the presence or absence of convergence toward diffuse share ownership. Our starting point is a simple OLS regression of the functional form: $\ln \left(\varphi(t) / \varphi_{0}\right)=f\left(\ln \varphi_{0}\right.$, XLs, relevant control variables) where $\varphi(t)$ is the

Review of Law \& Economics, ( 2007 by bepress 
current level of inside ownership concentration, $\varphi_{0}$ is the initial level of inside ownership concentration, and XLs is the proxy for the effect of cross-listings on U.S. stock exchanges. If the coefficient on $\ln \varphi_{0}$ is significantly negative, the distance between the initial (high) and current levels of share ownership concentration shrinks over the sample period. In this case, corporate ownership converges toward the Berle-Means image. Alternatively, if the coefficient on $\ln \varphi_{0}$ is not far from zero, cross-country differences in share ownership concentration persist over time.

Similarly, the statistical significance of XLs lends credence to the case for functional convergence toward diffuse ownership due to the legal consequences of cross-listings on U.S. stock exchanges. In this case, companies that operate in countries with lax ownership limits are said to converge to the Berle-Means image via their cross-listings in the U.S. Also, we add a number of variables that reflect each country's characteristics in terms of governance, legal origin, political orientation, and colonial endowment. The inclusion of control variables permits us to carry out robustness checks on the empirical results.

\subsection{DATA}

We collect data from a number of sources. The proxies for share ownership concentration come from Thomson Financials' Worldscope database. These factors correspond to closely held shares recorded on Worldscope. Worldscope defines closely held shares in percentage terms to include the shares held by insiders such as directors, officers, and immediate family, those shares held in trust, by any institutional investor such as other corporations, pension funds, or benefit plans, as well as those shares held by individuals who own 5 percent or more of all outstanding shares. We measure the company's prevailing level of share ownership concentration as the percentage of closely held shares at the end of 2003. Also, we measure the company's initial level of ownership concentration as the percentage of closely held shares at the end of a year during the period from 1994 to 1999. This year provides the greatest number of companies over the 5-year period. This measurement allows us to acquire a sufficient number of countries for this empirical work. Table 2 reports the number of companies in each of the 46 countries that we include in the sample. As a last step, we take the average of share ownership concentration percentages for all companies in a country and then use this average as the typical level of share ownership concentration for that country.

In addition to the share ownership data, we use country-level factors to capture the differences in the wider legal, governance, and geopolitical environment. We use the World Bank's governance data, "Governance Matters III", to describe the quality of governance in each sample country. In brief 
terms, this database sheds light on the key aspects of each sample country's wide framework of governance such as voice and accountability, political stability, absence of violence, govern-ment effectiveness, quality of regulation, rule of law and control of corruption (Kaufmann, Kraay, and Mastruzzi, 2003).

Table 2: Number of companies in each of the 46 sample countries

\begin{tabular}{|c|c|c|}
\hline Country Name & Year 1994 1999 & Year 2003 \\
\hline Australia & 70 & 524 \\
\hline Austria & 11 & 33 \\
\hline Belgium & 48 & 60 \\
\hline Brazil & 34 & 36 \\
\hline Canada & 53 & 104 \\
\hline Czech Republic & 16 & 13 \\
\hline Switzerland & 52 & 131 \\
\hline Chile & 42 & 71 \\
\hline China & 60 & 147 \\
\hline Germany & 172 & 255 \\
\hline Denmark & 31 & 62 \\
\hline Spain & 36 & 69 \\
\hline Finland & 46 & 68 \\
\hline France & 178 & 304 \\
\hline United Kingdom & 565 & 1,057 \\
\hline Greece & 23 & 25 \\
\hline Hong Kong & 107 & 468 \\
\hline Hungary & 12 & 16 \\
\hline Indonesia & 54 & 143 \\
\hline India & 11 & 144 \\
\hline Ireland & 18 & 30 \\
\hline Israel & 13 & 43 \\
\hline Italy & 24 & 102 \\
\hline Japan & 346 & 1,156 \\
\hline South Korea & 99 & 333 \\
\hline
\end{tabular}

Review of Law \& Economics, (C) 2007 by bepress 
Path Dependence or Convergence? / 533

\begin{tabular}{|ccc|} 
Mexico & 7 & 12 \\
Malaysia & 160 & 468 \\
Netherlands & 61 & 70 \\
Norway & 37 & 61 \\
New Zealand & 12 & 49 \\
Pakistan & 10 & 34 \\
Peru & 8 & 12 \\
Philippines & 31 & 72 \\
Poland & 16 & 26 \\
Portugal & 13 & 19 \\
Russia & 7 & 16 \\
Singapore & 58 & 286 \\
Sweden & 56 & 98 \\
Thailand & 55 & 225 \\
Turkey & 15 & 99 \\
Taiwan & 14 & 304 \\
United States & 1,328 & 2,700 \\
South Africa & 51 & 91 \\
\hline TOTAL & $\mathbf{4 , 0 6 0}$ & $\mathbf{1 0 , 0 3 6}$ \\
\hline
\end{tabular}

We use Marshall and Jaggers' (2003) data, "Polity IV", to reflect the characteristics of the political regimes in the sample countries. These characteristics include the general degree of openness or closeness of political institutions, the wedge between the degrees of both openness and closeness of these institutions, and the number of years that a given regime has persisted since 1872 .

In order to capture the effect of cross-listings on share ownership, we use Reese and Weisbach's (2002) data on the number of non-U.S. companies' crosslistings in the U.S. We draw from their data a couple of proxies for the number of these cross-listings. The first proxy measures the ratio of the number of a sample country's publicly listed companies that cross-list on the major U.S. stock exchanges relative to the total number of the country's publicly listed companies. Similarly, the second proxy measures the ratio of the number of a given country's publicly listed companies that cross-list on either NYSE or Nasdaq to the total number of the country's listed companies. 
We use La Porta et al.'s (2004) data on legal origin to find whether a given country's legal regime belongs to the British, French, Scandinavian, or German family. In addition, we use Acemoglu et al.'s (2001) data on institutional endowments to capture differences in the disease and geographic environment. The endowment factors include the absolute value of the latitude of a country, the presence or absence of tropical climate in a nation, and the receptiveindirect versus unreceptive-direct nature of colonial transplants.

We use Esty et al.'s (2005) sustainability indices to reflect several aspects of a given country's level of sustainability. These aspects encompass environmental sustainability, ecosystem stress, human sustenance, institutional governance, and global stewardship. These indices complement the use of Acemoglu et al.'s (2001) proxies for the quality of each sample country's disease or geographic environment.

Table 3 reports the data variables, descriptions, mathematical notations, and sources by category.

Table 3: Data variables, descriptions, mathematical notations, and sources by category

\begin{tabular}{|clc|}
\hline Variable & Description & Source \\
\hline \hline Ownership & & \\
\hline$\varphi_{0}$ & $\begin{array}{l}\varphi 0 \text { denotes the value of closely held shares } \\
\text { expressed as an average percentage of the } \\
\text { value of total common shares outstanding for } \\
\text { each sample country during 1994-1999. }\end{array}$ & Worldscope \\
\hline$\varphi(t)$ & $\begin{array}{l}\varphi(t) \text { denotes the value of closely held shares } \\
\text { expressed as an average percentage of total } \\
\text { common shares outstanding for each sample } \\
\text { country at the end of 2003. }\end{array}$ & Worldscope \\
\hline Governance & & \\
\hline \multirow{5}{*}{ Govern } & $\begin{array}{l}\text { Govern denotes the arithmetic average of the } \\
\text { 0-100 indicators of a) voice and } \\
\text { accountability ('Voice'), b) political stability } \\
\text { and absence of violence ('Politics'), c) } \\
\text { government effectiveness ('GovtEff'), d) } \\
\text { regulatory quality ('RegQ'), e) rule of law } \\
\text { ('Law'), and f) control of corruption ('Corru'). }\end{array}$ \\
\hline
\end{tabular}

Review of Law \& Economics, ( 2007 by bepress 
Path Dependence or Convergence? / 535

\begin{tabular}{|c|c|c|}
\hline Voice & $\begin{array}{l}\text { Voice denotes 'Voice and Accountability' as covered } \\
\text { in the 'Governance Matters III database', including } \\
\text { such areas as: political process, civil liberties, and } \\
\text { political rights. }\end{array}$ & $\begin{array}{c}\text { World Bank; Kaufmann, Kraay, } \\
\text { and Matruzzi (2003) }\end{array}$ \\
\hline Politics & $\begin{array}{l}\text { Politics denotes 'Political Stability and Absence of } \\
\text { Violence' as covered in the 'Governance Matters III } \\
\text { database,' encompassing such areas as: likelihood of } \\
\text { wrenching changes in government due to } \\
\text { unconstitutional means, domestic violence, or } \\
\text { terrorism. }\end{array}$ & $\begin{array}{l}\text { World Bank; Kaufmann, Kraay, } \\
\text { and Matruzzi (2003) }\end{array}$ \\
\hline GovtEff & $\begin{array}{l}\text { GovtEff denotes 'Government Effectiveness' as } \\
\text { covered in the 'Governance Matters III database', } \\
\text { encompassing such areas as: Quality of public } \\
\text { service provision and bureaucracy, competency of } \\
\text { civil servants, credibility of government's policy } \\
\text { commitments, and independence of civil services } \\
\text { from political pressures. }\end{array}$ & $\begin{array}{l}\text { World Bank; Kaufmann, Kraay, } \\
\text { and Matruzzi (2003) }\end{array}$ \\
\hline $\operatorname{Reg} Q$ & $\begin{array}{l}\text { RegQ denotes 'Quality of Regulation' as covered in } \\
\text { the 'Governance Matters III database', } \\
\text { encompassing such areas as: Incidence of } \\
\text { market-unfriendly policies and perceived burdens } \\
\text { imposed by excessive regulation. }\end{array}$ & $\begin{array}{c}\text { World Bank; Kaufmann, Kraay, } \\
\text { and Matruzzi (2003) }\end{array}$ \\
\hline Law & $\begin{array}{l}\text { Law denotes 'Rule of Law' as covered in the } \\
\text { 'Governance Matters III database', encompassing } \\
\text { such areas as: perceptions of the incidence of crime, } \\
\text { the effectiveness and predictability of the judiciary, } \\
\text { and the enforceability of contracts. }\end{array}$ & $\begin{array}{l}\text { World Bank; Kaufmann, Kraay, } \\
\text { and Matruzzi (2003) }\end{array}$ \\
\hline Corru & $\begin{array}{l}\text { Corru denotes 'Control of Corruption' as covered in } \\
\text { the 'Governance Matters III database', } \\
\text { encompassing such areas as: perceptions of } \\
\text { corruption (conventionally defined as the exercise of } \\
\text { public power for private gain). }\end{array}$ & $\begin{array}{c}\text { World Bank; Kaufmann, Kraay, } \\
\text { and Matruzzi (2003) }\end{array}$ \\
\hline \multicolumn{3}{|c|}{ Sustainability } \\
\hline ESI & $\begin{array}{l}\text { ESI denotes the arithmetic average of the following } \\
\text { five sustainability indicators: a) environmental } \\
\text { sustainability, b) ecosystem stress, c) human } \\
\text { sustenance, d) institutional governance, and e) global } \\
\text { stewardship. }\end{array}$ & $\begin{array}{l}\text { Yale Center for Environmental } \\
\text { Law and Policy; Esty, Levy, } \\
\text { Srebotnjak, and de Sherbinin } \\
\text { (2005). }\end{array}$ \\
\hline
\end{tabular}




\begin{tabular}{|c|c|c|}
\hline Environ & $\begin{array}{l}\text { Environ denotes the indicator variable that describes } \\
\text { the relative degree of air quality, water quantity and } \\
\text { quality, biodiversity, and terrestrial systems in a } \\
\text { given country. }\end{array}$ & $\begin{array}{l}\text { Yale Center for Environmental } \\
\text { Law and Policy; Esty, Levy, } \\
\text { Srebotnjak, and de Sherbinin } \\
\text { (2005). }\end{array}$ \\
\hline Stress & $\begin{array}{l}\text { Stress denotes the indicator variable that describes } \\
\text { the relative degree of policy remedies for air } \\
\text { pollution, water stress, ecosystem stress, waste and } \\
\text { consumption pressures, resource management, and } \\
\text { population pressure. }\end{array}$ & $\begin{array}{l}\text { Yale Center for Environmental } \\
\text { Law and Policy; Esty, Levy, } \\
\text { Srebotnjak, and de Sherbinin } \\
\text { (2005). }\end{array}$ \\
\hline Human & $\begin{array}{l}\text { Human denotes the indicator variable that describes } \\
\text { the relative degree of basic human sustenance and } \\
\text { environmental health. }\end{array}$ & $\begin{array}{l}\text { Yale Ctr for Environmental Law } \\
\text { and Policy; Esty, Levy, } \\
\text { Srebotnjak, and de Sherbinin } \\
\text { (2005). }\end{array}$ \\
\hline Institu & $\begin{array}{l}\text { Institu denotes the indicator variable that describes } \\
\text { the relative degree of advances in science and } \\
\text { technology, capacity for debate, private sector } \\
\text { responsiveness, environmental governance, and } \\
\text { eco-efficiency. }\end{array}$ & $\begin{array}{l}\text { Yale Center for Environmental } \\
\text { Law and Policy; Esty, Levy, } \\
\text { Srebotnjak, and de Sherbinin } \\
\text { (2005). }\end{array}$ \\
\hline Globalss & $\begin{array}{l}\text { Globalss denotes the indicator variable that } \\
\text { describes the relative degree of participation in } \\
\text { international cooperative efforts and policies } \\
\text { designed to minimize greenhouse gas emissions } \\
\text { and transboundary environmental pressures. }\end{array}$ & $\begin{array}{l}\text { Yale Center for Environmental } \\
\text { Law and Policy; Esty, Levy, } \\
\text { Srebotnjak, and de Sherbinin } \\
\text { (2005). }\end{array}$ \\
\hline \multicolumn{3}{|l|}{ Politics } \\
\hline Polity & $\begin{array}{l}\text { Polity denotes the regime's institutionalized } \\
\text { authority characteristics (measured as the } \\
\text { difference between 'Democ' and 'Autoc' (see } \\
\text { below)). }\end{array}$ & $\begin{array}{l}\text { Polity IV Project by Marshall } \\
\text { and Jaggers (2003) }\end{array}$ \\
\hline Persist & $\begin{array}{l}\text { Persist denotes that number of years } \\
\text { (rounded) that a particular polity case or a } \\
\text { politically independent regime has persisted } \\
\text { since } 1872 \text {. }\end{array}$ & $\begin{array}{l}\text { Polity IV Project by Marshall } \\
\text { and Jaggers (2003) }\end{array}$ \\
\hline Democ & $\begin{array}{l}\text { Democ denotes the democracy score as } \\
\text { covered in the 'Polity IV Project', describing } \\
\text { the general openness of political institutions. }\end{array}$ & $\begin{array}{l}\text { Polity IV Project by Marshall } \\
\text { and Jaggers (2003) }\end{array}$ \\
\hline Autoc & $\begin{array}{l}\text { Autoc denotes the autocracy score as covered } \\
\text { in the 'Polity IV Project', describing the general } \\
\text { closeness of political institutions. }\end{array}$ & $\begin{array}{l}\text { Polity IV Project by Marshall } \\
\quad \text { and Jaggers (2003) }\end{array}$ \\
\hline
\end{tabular}

Review of Law \& Economics, (C 2007 by bepress 
Path Dependence or Convergence? / 537

\begin{tabular}{|c|c|c|}
\hline \multicolumn{3}{|l|}{ Cross-listings } \\
\hline CL100 & $\begin{array}{l}\text { CL100 denotes the number of non-U.S. firms } \\
\text { that cross-listed their shares or ADRs on all } \\
\text { major U.S. stock exchanges (NYSE, Nasdaq, } \\
\text { OTC and PORTAL) between January } 1985 \\
\text { and June } 1999, \text { expressed as a proportion of } \\
\text { the number of listed companies for a given } \\
\text { country. }\end{array}$ & $\begin{array}{c}\text { Reese and Weisbach } \\
\text { (JFE 2002) }\end{array}$ \\
\hline NNCL100 & $\begin{array}{l}\text { NNCL100 denotes the number of non-U.S. } \\
\text { firms that cross-listed their shares or ADRs on } \\
\text { NYSE or Nasdaq between January } 1985 \text { and } \\
\text { June } 1999 \text {, expressed as a proportion of the } \\
\text { number of listed companies for a given } \\
\text { country. }\end{array}$ & $\begin{array}{l}\text { Reese and Weisbach } \\
\text { (JFE 2002) }\end{array}$ \\
\hline \multicolumn{3}{|l|}{ Legal origin } \\
\hline Engmo & $\begin{array}{l}\text { Engmo denotes the dummy variable that } \\
\text { carries a value of } 1 \text { for a country with the } \\
\text { British legal origin and } 0 \text { otherwise. }\end{array}$ & La Porta et al. (2006) \\
\hline FRSPmo & $\begin{array}{l}\text { FRSPmo denotes the dummy variable that } \\
\text { carries a value of } 1 \text { for a country with the } \\
\text { French or Spanish legal origin and } 0 \\
\text { otherwise. }\end{array}$ & La Porta et al. (2006) \\
\hline Scandmo & $\begin{array}{l}\text { Scandmo denotes the dummy variable that } \\
\text { carries a value of } 1 \text { for a country with the } \\
\text { Scandinavian legal origin and } 0 \text { otherwise. }\end{array}$ & La Porta et al. (2006) \\
\hline Germmo & $\begin{array}{l}\text { Germmo denotes the dummy variable that } \\
\text { carries a value of } 1 \text { for a country with the } \\
\text { German legal origin and } 0 \text { otherwise. }\end{array}$ & La Porta et al. (2006) \\
\hline \multicolumn{3}{|l|}{ Endowments } \\
\hline Latitude & $\begin{array}{l}\text { Latitude denotes the absolute value of the } \\
\text { latitude of a country, as measured by La } \\
\text { Porta et al. }\end{array}$ & $\begin{array}{l}\text { Acemoglu et al. } \\
\text { (AER 2001) }\end{array}$ \\
\hline Tropical & $\begin{array}{l}\text { Tropical denotes the presence or absence } \\
\text { of tropical climate. This dummy variable } \\
\text { equals } 1 \text { if the country is in a tropical- } \\
\text { climate zone. }\end{array}$ & $\begin{array}{l}\text { Acemoglu et al. } \\
\text { (AER 2001) }\end{array}$ \\
\hline Transplant & $\begin{array}{l}\text { Transplant denotes the sum of indicator- } \\
\text { variables for receptive-indirect transplants, } \\
\text { unreceptive direct transplants, and } \\
\text { unreceptive in-direct transplants. }\end{array}$ & $\begin{array}{l}\text { Acemoglu et al. } \\
\text { (AER 2001) }\end{array}$ \\
\hline
\end{tabular}




\subsection{DESCRIPTIVE STATISTICS}

Table 4 reports the descriptive statistics and correlations for the above variables. The bold figures indicate statistical significance at the 95 percent confidence level. At first glance, we note the high correlations among the variables that fall in each of these categories (see also the shaded cells). For instance, countries in which citizens can readily raise their voice in the political arena (high scores on Voice, Politics and Law) seem to have better legal enforcement, quality of regulation, and control of corruption (high scores on GovtEff, RegQ, Law and Corru). This pattern poses a possible issue of multicollinearity in ordinary least squares (OLS) regressions. Multicollinearity occurs whenever two or more explanatory variables are highly correlated so that the significance of one or more of these variables swamps the significance of other variables. We leave this issue to Section 3.4 in which we check the robustness of our OLS regression results. In that section we add each set of related explanatory variables one at a time to see if the initial level of inside share ownership concentration persists.

The remaining cells offer some preliminary results. Firstly, the prevailing level of share ownership concentration, $\varphi(t)$, is positively correlated to the initial counterpart, $\varphi_{0}$. This finding accords with the view that share ownership concentration seems to persist (see also Eq.(6)). Secondly, we find that the governance indices are all negatively related to the measures of share ownership concentration, $\varphi_{0}$ and $\varphi(t)$. This finding is not surprising and echoes the core prediction of Eq.(6) and the recent law-and-finance literature (La Porta et al., 1999). Thirdly, cross-listing activity is positively correlated to the quality of governance. All except one correlation between CL100 and GovtEff are insignificant. In turn, we see such positive correlations as indicative of the possibility that more facilitative regimes tend to encourage companies to seek capital in the U.S. Finally, the rest of Table 4 shows low correlations. These correlations imply that the corresponding variables may contain independent and useful information about the current level of share ownership concentration $\varphi(t)$.

\subsection{REGRESSION RESULTS}

We use the standard convergence tests widely accepted in the literature on economic growth (see also the work by Barro (1991), Barro and Sala-i-Martin (1992), and Sala-i-Martin (1996), among others). These tests help investigate the case for conditional $\beta$ convergence: "...the prediction of the neoclassical [growth] model is that the growth rate of an economy will be positively related to the distance that separates it from its own steady state" (Sala-i-Martin, 1996:1027). In the macro-economic context conditional $\beta$ convergence occurs if growth rates are negatively related to initial growth levels after adjusting for

Review of Law \& Economics, ( 2007 by bepress 
Path Dependence or Convergence? / 539

institutional factors that define the steady state for each country. We apply the test for conditional $\beta$ convergence to empirically assess the central prediction of the model derived in Section 2. Specifically, we run OLS regressions of the following first-differences on levels form:

$$
\ln \frac{\varphi(\mathrm{t})}{\varphi_{0}}=\beta_{0}+\beta_{\varphi} \ln \varphi_{0}+\sum \beta_{\mathrm{i}} \chi_{\mathrm{i}}+\varepsilon
$$

where $\varphi(t)$ is the current level of share ownership concentration,

$\varphi_{0}$ is the initial level of share ownership concentration,

$\chi_{i}$ is the $i^{\text {th }}$ control variable, such as governance, cross-listings, legal

origin, and so forth,

$\beta_{0}, \beta_{\varphi}$, and $\beta_{i}$ denote the respective coefficients, and

$\varepsilon$ is the white-noise residual term.

If the effect of path dependent forces is at best minimal, we expect $\beta_{\varphi}$ to be close to nil under the null that the initial level of share ownership concentration has no implication for the terrain upon which this level of concentration persists or shrinks over time. The quantitative results bolster the opposite story. In particular, we find that $\beta_{\varphi}$ is significantly negative but statistically far from -1 in all regressions. Table 5 presents these regression results. In Panel A, the first row of each model shows the coefficients and the second row shows the corresponding t-statistics. The bold figures indicate significance at the 95 percent confidence level. Below we discuss each regression in detail.

\subsubsection{Path dependence, legal origin, and asset endowment}

Regressing the log difference between the initial and prevailing levels of share ownership concentration on the initial level of share ownership concentration yields a significantly negative relation between these variables. We note that $\beta_{\varphi}$ is not only significantly negative but also far from -1 ( $\mathrm{t}$-stat=-4.26). We also note that this result is robust to all alternative model specifications below. In addition, $\beta_{\varphi}$ varies between -0.634 and -0.739 . This result suggests that the log distance between the initial and prevailing levels of share ownership concentration is likely to shrink by 7 percent in response to a 10-percentage increase in the initial level of ownership concentration. We note that this result suggests partial convergence or the existence of path dependent forces $\left(-1<\beta_{\varphi}<0\right)$.

We then add proxies for legal origin to the regression. None of these dummy variables appear to be significant. This result is not consistent with the La Porta 
et al. studies, which suggest that share ownership tends to be more diffuse in common-law regimes than in civil-law regimes. A possible explanation for this result is that the predictive power of $\varphi_{0}$ overwhelms the effect of factors that reflect a given country's legal tradition.

Next, we substitute the proxies for legal origin with a set of proxies for the wider disease geographic environment: latitude, location in or out of a tropicalclimate zone, and degree of receptive-ness of colonial transplants. The regression reports that a country's location in a tropical-climate zone seems to be associated with less diffuse share ownership (t-stat=1.707). This result accords with recent studies: the geographic environment shaped the colonizer's settlement strategy and so affected subsequent corporate ownership and power-sharing structures. But this association does not affect the explanatory power of $\varphi_{0}$. In brief, share ownership concentration appears to persist or partially shrink even after controlling for the effect of endowment factors.

\subsubsection{Path Dependence, Quality of Governance, and Politics}

We add a number of variables for the quality of governance to the regression. Again, $\beta_{\varphi}$ continues to be reliably negative $(t-s t a t=-8.954)$. This result confirms the persistence of differences in share ownership concentration. We also find a negative association between the log changes in the level of ownership concentration and the quality of governance $(t-s t a t=-3.3)$. This negative association accords with the prediction of Eq.(9) and the law-and-finance theme: "ownership concentration serves as a substitute for poor investor protection" (La Porta et al., 1999:473-474, 497).

We then replace the proxy for the overall quality of governance with each of its constituents and find very similar results. After controlling for the variation in the initial level of share ownership concentration, each of these constituents (access to political rights, political stability, government effectiveness, quality of regulation, rule of law, and control of corruption) has a reliable negative association with the log changes in the level of share ownership concentration ( $t$ stat $\approx-3$ ). Hence, strong legal enforcement is quite effective in dampening share ownership concentration.

We further study the effect of political orientation on the dispersion of share ownership. We find a robust negative link between the log changes in the level of share ownership concentration and the number of years since the country's date of official independence ( $\mathrm{t}$-stat $=-2.718$ ). This result suggests that populist politics takes time to develop and further to expand the dispersion of share ownership. However, we find no clear link between the relative openness or closeness of political institutions and the log changes in the level of ownership concentration.

Review of Law \& Economics, ( 2007 by bepress 
Path Dependence or Convergence? / 541

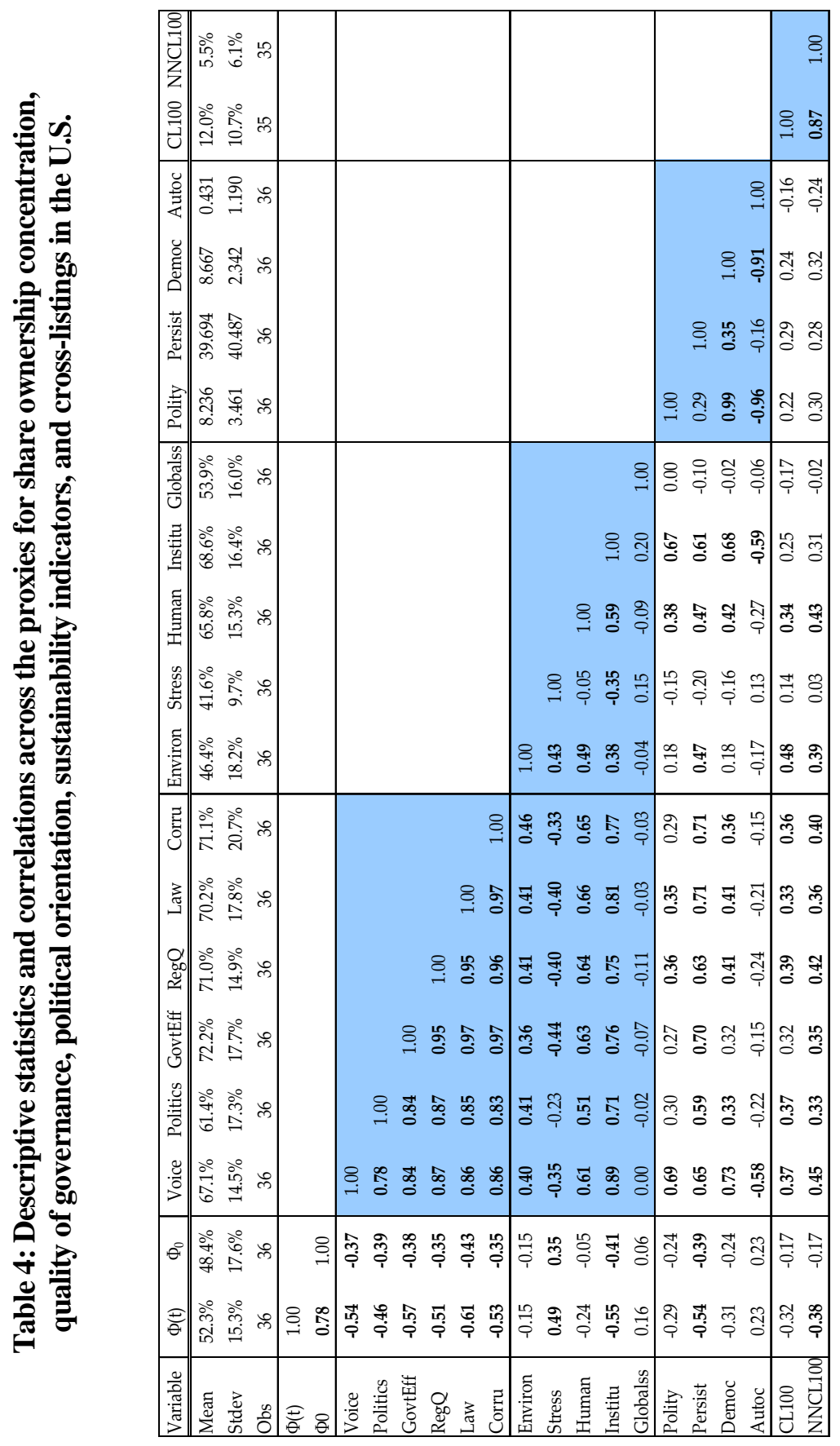




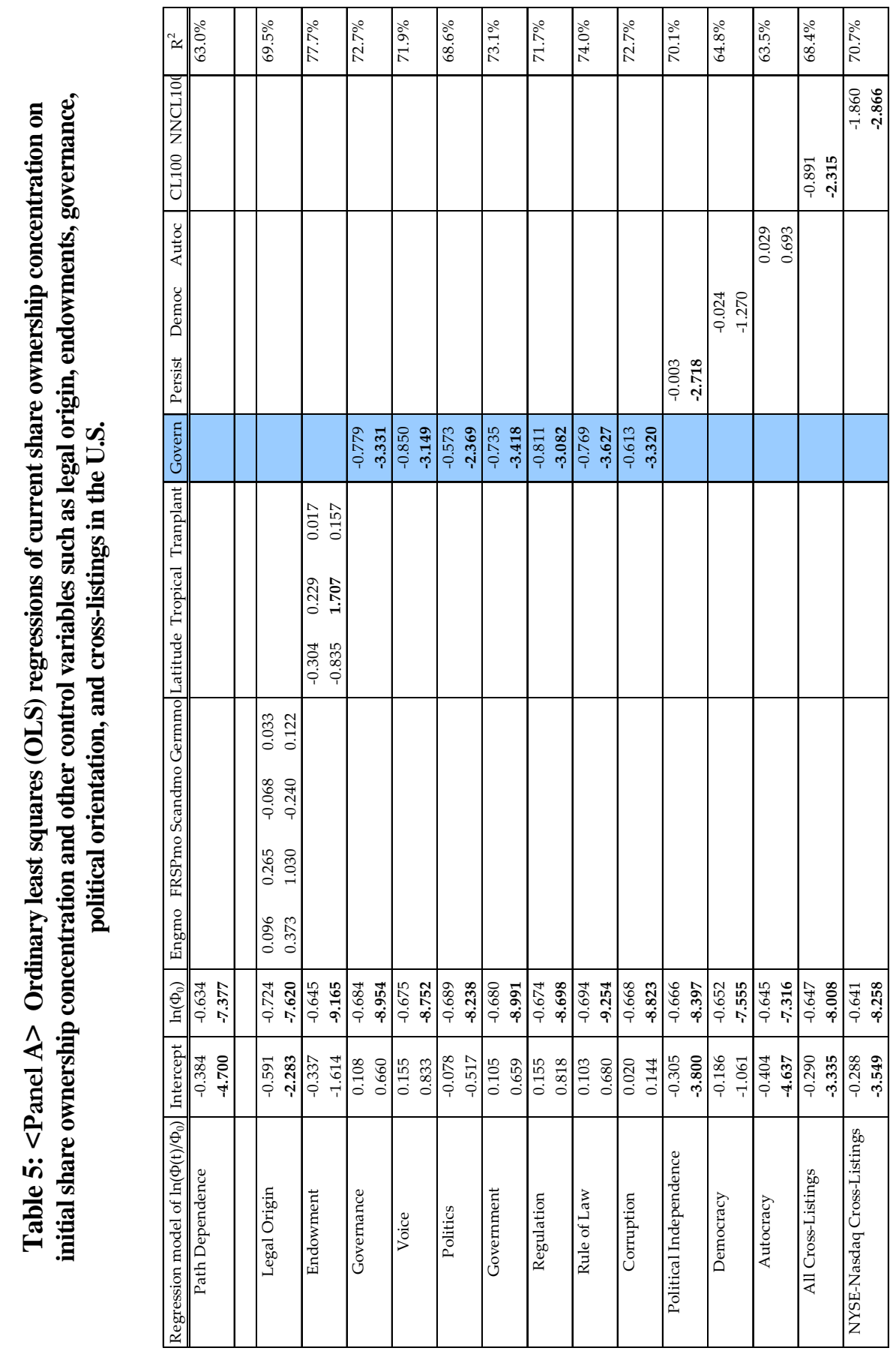

Review of Law \& Economics, ( 2007 by bepress 
Path Dependence or Convergence? / 543

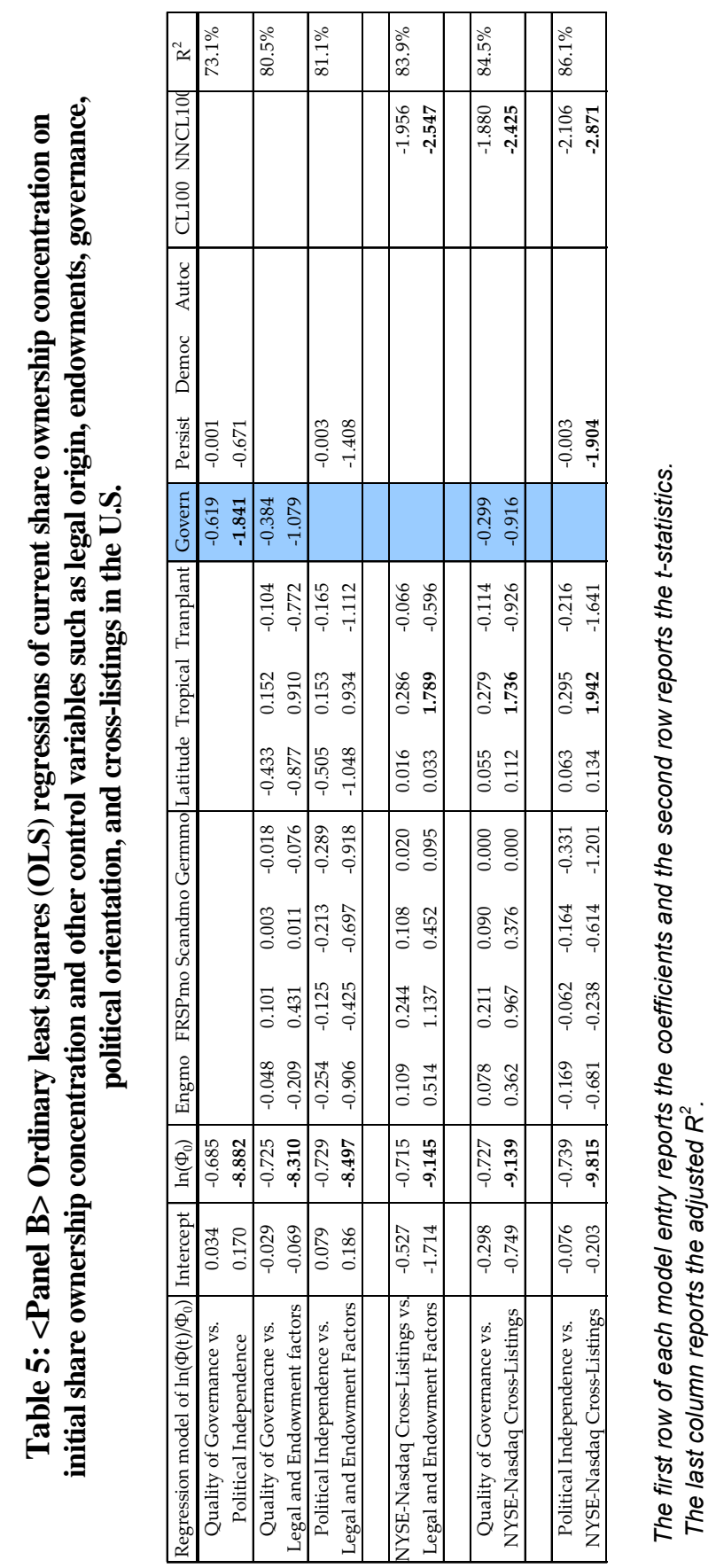




\subsubsection{Path dependence and functional convergence}

We next explore the effect of cross-listings on U.S. stock exchanges. This exploration rests upon the hypothesis that cross-listings on NYSE and Nasdaq could induce convergence toward diffuse share ownership by subjecting nonU.S. listed companies to stringent disclosure, accounting and registration rules. These rules raise the costs for non-U.S. companies to uphold the level of share ownership concentration. These cross-listed companies may then imitate the Berle-Means image.

Below we report some evidence in support for the case of functional convergence. CL100 carries a significantly negative coefficient $(t-s t a t=-2.315)$. Further, NNCL100 has a significantly negative coefficient (t-stat=-2.87). In both cases, $\ln \varphi_{0}$ has a significantly negative effect on the log changes in the level of ownership concentration (t-stat $\approx-8)$. We note that $\beta_{\varphi}$ lands comfortably within the range between -1 and 0 . In turn, this finding confirms partial convergence towards diffuse share ownership or the existence of some path dependent forces. Therefore, the path dependence and convergence views need not be mutually exclusive. While the path-dependence story portrays the static part of the picture, the case for functional convergence better paints the more dynamic part. Both stories complement each other in capturing the log movements in ownership concentration.

\subsection{ROBUSTNESS CHECKS}

We now run some additional tests to better understand the main determinants of the variation in share ownership concentration. Panel B of Table 5 presents the results.

\subsubsection{Legal Protection Versus Political Independence}

So far we have found some support for the proxies for quality of governance, the effect of cross-listings, and the number of years of political independence. We now add variables for legal origin and endowment to check the robustness of the results. We report the main results in Panel B of Table 5. When both the quality of governance and the number of years of political independence enter the regression along with the legal and endowment control factors, we find that none of the control variables are significant. The only significant variable is $\ln \varphi_{0}(t-s t a t=-8.882)$. In fact, these findings could imply certain multicollinearity between the legal and political conditions. The legal and political theories of corporate finance might have their own merits. It is our conjecture that both theories could reinforce each other to some extent.

Review of Law \& Economics, ( 2007 by bepress 


\subsubsection{Legal and Endowment Variables Versus NYSE-Nasdaq Cross-Listings}

When we add the percentage of non-U.S. corporations that cross-list on NYSE or Nasdaq to the regression along with the legal and endowment control factors, we observe that there is a reliable bonding effect of cross-listings ( $t$ stat $=-2.547)$. We also find support for path dependence as the coefficient on $\ln \varphi_{0}$ falls in the range between -1 and 0 ( $t$-stat $=-9.145 ;-1<\beta_{\varphi}=-0.715<0$ ). Once again, this finding suggests partial convergence to Berle-Means diffuse ownership or the existence of path dependence forces on share ownership concentration. We note that this result in support of the path dependence view persists in the next couple of subsections. We also note that another control factor, the presence of a tropical climate, is positively correlated to the persistent distance between the initial and prevailing levels of share ownership concentration at the 95 percent confidence level ( $\mathrm{t}-\mathrm{stat}=1.789)$.

We report that cross-listings on NYSE or Nasdaq help dampen share ownership concentration in the cross-section of the sample countries (t-stat $=$ 2.547). Further, $\beta_{\varphi}=-1.956$ suggests that there is likely to be a 2 percentage decrease in the $\log$ difference between the initial and prevailing levels of ownership concentration in response to a 1 percent rise in the proportion of non-U.S. listed companies that cross-list on NYSE or Nasdaq. Further, we note that this bonding effect of cross-listings on NYSE or Nasdaq is slightly stronger than the result in Section 3.3.3 (1.956>1.860).

\subsubsection{Quality of Governance Versus NYSE-Nasdaq Cross-Listings}

We include as explanatory factors the governance metrics, the percentage of non-U.S. companies that cross-list on NYSE or Nasdaq, the legal and endowment control factors, and the log initial level of share ownership concentration. A couple of control variables, $\ln \varphi_{0}$ and the presence of a tropical climate, continue to be significant. Also, the bonding effect of cross-listings continues to be strong ( $t$-stat $=-2.425)$. But the quality of governance loses explanatory power ( $\mathrm{t}$-stat $=-0.916)$. We interpret the above result as indicative of a lesser need for corporate law reform. A potential substitute could be market mechanisms that facilitate non-U.S. companies both to cross-list and to be subject to higher disclosure and listing standards (Goddard, 1996).

\subsubsection{Political Independence Versus NYSE-Nasdaq Cross-Listings}

We now include as explanatory variables the number of years since independence, the percentage of non-U.S. firms that cross-list on NYSE or Nasdaq, the legal and endowment control variables, and the log initial level of share ownership concentration. A couple of control variables, $\ln \varphi_{0}$ and the 
presence of a tropical climate, continue to be significant variables. The number of years since political independence is statistically significant at the 95 percent confidence level. In addition, we continue to observe the bonding effect of cross-listings on NYSE or Nasdaq. Hence, the case for functional convergence to diffuse share ownership is robust to alternative model specifications.

\subsection{A BRIEF SUMMARY OF EMPIRICAL RESULTS}

Below we summarise the key empirical results:

- Partial convergence toward the Berle-Means view of diffuse share ownership concentration prevails in all of the cross-sectional regressions. This finding suggests the existence of path dependencies in share ownership concentration.

- Cross-listings on NYSE or Nasdaq help facilitate the market mechanism for non-U.S. companies to be subject to U.S. rules that protect investor rights. Because these disclosure and listing rules impose limits on share ownership, convergence towards the Berle-Means form of diffuse ownership is possible. We find evidence in support of such convergence.

- There is a significantly negative link between the quality of governance and the log changes in the level of share ownership concentration. This finding accords with the core thesis that investors view control blocks as a substitute for poor legal protection.

\section{CONCLUSIONS}

We engage in the debate over whether corporate ownership concentration tends to persist or fall over time. This debate addresses the relevance of policy. According to Greenwood (2005), state control and de facto authority could swamp the effect of convergence to the Berle-Means image of diffuse corporate ownership. In this light, there would be little room for proper changes to the law to promote Berle-Means convergence. Convergence (or not) would be rather value neutral in a political world.

We disagree with Greenwood's view. We argue that even partial convergence could help promote welfare. But our current paper does not directly throw light on the link between convergence and welfare. A future exploration of the complementarities between legal and asset protections could help foster a better understanding of the above normative issue.

Review of Law \& Economics, ( 2007 by bepress 
The current paper focuses on the positive issue: is there evidence in support of the existing path-dependence or convergence views? In these existing views, cross-country differences in corporate ownership concentration might or might not shrink. Our model includes the importance of legal and asset-related protective arrangements. The core analytical finding is that corporate ownership concentration persists or falls depending on the relative importance of legal and asset protections. In particular, our model predicts (a) diffuse share ownership in nations that impose legal limits on blockholders' clout to expropriate minority shareholder rights, and (b) concentrated ownership in nations that rely on asset specificity as a form of investor protection. Our model predicts a non-linear negative relationship between the level of share ownership concentration and the degree of legal protection. Our central prediction echoes La Porta et al.'s (1997) thesis that share ownership concentration acts as a substitute for poor investor protection. Also, the analytical result presents the prevailing level of ownership concentration as a function of both the initial level of ownership concentration and legal and asset protections. The implicit relationship between legal protection and subsequent ownership concentration is hence causal. We observe that a causal link traverses from legal protection to corporate ownership concentration (but not vice versa). Specifically, the legal environment helps shape the trajectory upon which corporate ownership structures evolve over time. This latter point distinguishes our analysis from La Porta et al.'s recent empirical work. An additional note on asset specificity is that there is a nebulous non-linear relation between asset protection and corporate ownership concentration.

Our empirical work suggests partial convergence toward Berle-Means diffuse share ownership. It is thereby reasonable to infer the existence of path dependent forces on ownership concentration. But this result does not preclude the possibility of functional convergence or convergence to the diffuse form of share ownership through cross-listings on the U.S. stock exchanges that impose stringent disclosure and listing requirements. In essence, these findings support a case for the co-existence of the preexisting pathdependency and functional-convergence stories.

Finally, the determinants of persistence of share ownership concentration found in our empirical work should provoke future research that focuses on how these determinants could help enhance welfare. This research in turn throws light on how to 'race to the top' in setting a legal framework to capture the positive outcomes of Berle-Means convergence. 


\section{References}

Acemoglu, D., J. Robinson, and S. Johnson. 2001. "The Colonial Origins of Comparative Development: An Empirical Investigation,” 91 American Economic Review 1369.

Ayyagari, M. 2005. "Does Cross-Listing Lead to Functional Convergence? Some Empirical Evidence," World Bank Policy Paper \#3264, http://ssrn.com/abstract=610305 (accessed August 20, 2005).

Barro, R.J. 1991. "Economic Growth in a Cross-Section of Countries," 106 Quarterly Journal of Economics 407.

Barro, R.J. and Sala-i-Martin, X.X. 1992. "Convergence," 100 Journal of Political Economy 223.

Bebchuk, L.A. 1992. "Federalism and the Corporation: The Desirable Limits on State Competition in Corporate Law," 105 Harvard Law Review 1437.

. 1999. "A Rent Protection Theory of Corporate Ownership and Control," NBER Working Paper \#7203.

2002. "Asymmetric Information and the Choice of Corporate Ownership and Governance Arrangements," Harvard Law \& Economics Discussion Paper No. 398, http://papers.ssrn.com/sol3/papers.cfm?abstract_id=327842 (accessed 5/8/05). and A. Cohen. 2003. "Firms' Decisions Where to Incorporate," 10 Journal of Law and Economics 383.

, _ _ and A. Ferrell. 2002. "Does the Evidence Favor State Competition in Corporate Law?" 90 California Law Review 1775.

and A. Hamdani. 2002. "Vigorous Race or Leisurely Walk: Reconsidering the Competition Over Corporate Charters," 112 Yale Law Journal 553.

and C. Jolls. 1999. "Managerial Value Diversion and Shareholder Wealth," 15 Journal of Law, Economics and Organization 487.

, R. Kraakman, and G. Triantis. 1999. "Stock Pyramids, Cross-Ownership and Dual-Class Equity: The Mechanisms and Agency Costs of Separating Control from Cash Flow Rights," Harvard Law School Olin Discussion Paper \#249 (also published in Randall K. Morck ed., Concentrated Corporate Ownership, 2000:445-460). and M. Roe. 1999. "A Theory of Path Dependence in Corporate Ownership and Governance," 52 Stanford Law Review 127.

Benos, E., and M. Weisbach. 2004. "Private Benefits and Crosslistings in the United States," 5 Emerging Markets Review 217.

Black, B. 1990. "Shareholder Passivity Reexamined," 89 Michigan Law Review 520.

Blair, M.M., and L.A. Stout. 1999. "A Team Production Theory of Corporate Law," 85 Virginia Law Review 247. and 2001. "Trust, Trustworthiness, and the Behavioral Foundations of Corporate Law," 149 Univ. of Pennsylvania Law Review 1735.

Cary, W. 1974. "Federalism and Corporate Law," 83 Yale Law Journal 663.

Claessens, S., S. Djankov, and L. Lang. 2000. "The Separation of Ownership and Control in East Asian Corporations," 58 Journal of Financial Economics 81.

Coffee, J.C. 1991. "Liquidity Versus Control: The Institutional Investor as Corporate Monitor," 91 Columbia Law Review 1277.

Review of Law \& Economics, (C) 2007 by bepress 
. 1999. "The Future as History: The Prospect For Global Convergence In Corporate Governance And Its Implications," 93 Northwestern Law Rev. 641.

2001. "The rise of dispersed ownership: the role of law in the separation of ownership and control," 111 Yale Law Journal 1.

2001. "Do Norms Matter? A Cross-Country Examination of the Private Benefits Of Control," Columbia Law School Law and Economics Working Paper \#183, http://papers.ssrn.com/sol3/papers.cfm?abstract_id=257613 (accessed October 20, 2005).

. 2002. "Racing Towards the Top: The Impact of Cross-Listings and Stock Market Competition on International Corporate Governance," 102 Columbia Law Review 1757.

Cunningham, L. 1999. "Commonalities and Prescriptions in the Vertical Dimension of Global Corporate Governance," 84 Cornell Law Review 1133.

Demirguc-Kunt, A., and V. Maksimovic. 1998. "Law, Finance, and Firm Growth," 53 Journal of Finance 2107.

Demsetz, H. 1983. "The Structure of Ownership and the Theory of the Firm," 26 Journal of Law and Economics 375.

Dodd, P., and R. Leftwich. 1980. "The Market for Corporate Charters: 'Unhealthy Competition' Versus Federal Regulation," 53 Journal of Business 59.

Doidge, C. 2002. "U.S. cross-listings, private benefits of control, and ownership structure," Doctoral Thesis, Ohio State University. . 2004. "U.S. Cross-Listings and the Private Benefits of Control: Evidence from Dual-Class Firms," 71 Journal of Financial Economics 3. A. Karolyi, K.V. Lins, D.P. Miller, and R.M. Stulz. 2005. "Private benefits of control, ownership, and the cross-listing decision,” NBER Working Paper \#11162.

Easterbrook, F.H., and D.R. Fischel. 1991. The Economic Structure of Corporate Law.

Esty, D.C., M. Levy, T. Srebotnjak, and A. de Sherbinin. 2005. "Environmental sustainability index: benchmarking national environmental stewardship," Yale Center for Environmental Law and Policy, also at http://www.yale.edu/esi.

Fama, E. 1980. "Agency Problems and the Theory of the Firm," 88 Journal of Political Economy 288.

Frye, T., and A. Shleifer. 1997. "The Invisible Hand and the Grabbing Hand," 87 American Economic Review 354.

Goddard, D. 1996. "Convergence in Corporations Law - Towards a Facilitative Model," 26 Victoria University of Wellington Law Review 191.

Gordon, J.N. 1999. "Pathways to Corporate Convergence? Two Steps on the Road to Shareholder Capitalism in Germany," 5 Columbia Journal of European Law 219.

Greenwood, D. 2005. "The Mysterious Race to the Top or Bottom," 23 Yale Law and Policy Review 381.

Hansmann, H., and Kraakman, R. 2004. “The End of History for Corporate Law," in J. Gordon and M.J. Roe, eds. Convergence and Persistence in Corporate Governance 33-68.

Himmelberg, C., G. Hubbard, and I. Love. 2002. "Investor Protection, Ownership and Investment," Columbia Business School and World Bank Policy Research 
Paper \#2834, http://papers.ssrn.com/sol3/papers.cfm?abstract_id=303969 (accessed June 20, 2005).

Jensen, M.C., and W. Meckling. 1976. “Theory of the Firm: Managerial Behavior, Agency Costs, and Ownership Structure," 3 Journal of Financial Economics 305.

Jensen, M. 1986. "Agency Costs of Free Cash Flow, Corporate Finance, and Takeovers," 76 American Economic Review 323.

Jolls, C., C.R. Sunstein, and R. Thaler. 1998. "A Behavioral Approach to Law and Economics," 50 Stanford Law Review 1471.

Kissane, M.E. 1997. "Global Gadflies: Applications and Implications of U.S.-Style Corporate Governance Abroad," 17 New York Law School Journal of International and Competition Law.

Kaufmann, D., A. Kraay, and M Mastruzzi. 2003. “Governance Matters III: Governance Indicators for 1996-2002,” World Bank Policy Research Working Paper \#3106, http://www.worldbank.org/wbi/governance/pubs/govmatters3.html.

La Porta, R., F. Lopez-de-Silanes, A. Shleifer, and R. Vishny. 1997. "Legal Determinants of External Finance," 52 Journal of Finance 1131.

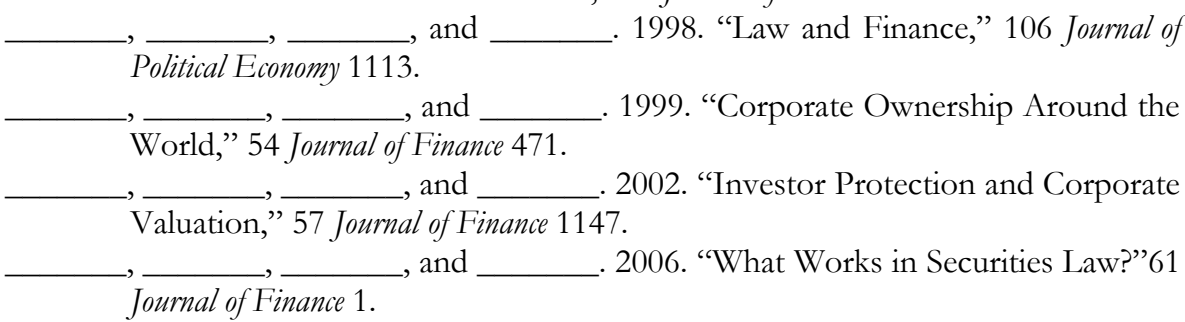

Licht, A. 2001. "The Mother of All Path Dependencies: Toward a Cross-Cultural Theory of Corporate Governance Systems," 26 Delaware Journal of Corporate Law 147.

Lipset, S.M., and W. Schneider. 1987. The Confidence Gap: Business, Labor and Government in the Public Mind. New York: The Free Press.

Marshall, M.G., and K. Jaggers. 2003. "Polity IV: political regime characteristics and transitions," see also http://www.cidcm.umd.edu/inscr/polity.

Maug, E. 1998. "Large Shareholders as Monitors: Is There a Trade-Off Between Liquidity and Control?" 53 Journal of Finance 1.

Rajan, R.G., and L. Zingales. 1998. "Power in the Theory of a Firm," 113 Quarterly Journal of Economics 387.

Roe, M.J. 1991. “A Political Theory of American Corporate Finance,” 91 Columbia Law Review 10.

. 1993. "Some Differences in Corporate Structure in Germany, Japan and the United States," 102 Yale Law Journal 8.

1994. Strong Managers, Weak Owners: The Political Roots of American Corporate Finance. Princeton University Press.

. 2000. "Political Preconditions to Separating Ownership From Corporate Control," Columbia Law School Working Paper \#155.

Romano, R. 1985. "Law as a Product: Some Pieces of the Incorporation Puzzle," 1 Journal of Law and Economics and Organization 225.

Review of Law \& Economics, (C 2007 by bepress 
Path Dependence or Convergence? / 551

1993. The Genius of American Corporate Law. AEI Press.

Sala-i-Martin, X.X. 1996. "The Classical Approach to Convergence Analysis," 106 Economic Journal 1019.

Shleifer, A., and R.W. Vishny. 2002. The Grabbing Hand: Government Pathologies and their Cures. Harvard University Press.

Winter, R. 1977. "State Law, Shareholder Protection and the Theory of the Corporation," 6 Journal of Legal Studies 271. 